\title{
Is vulnerability to climate change gendered? And how? Insights from Egypt
}

\author{
Mona Daoud ${ }^{1}$ (iD \\ Received: 10 April 2020 / Accepted: 30 April 2021 / Published online: 15 May 2021 \\ (C) The Author(s) 2021
}

\begin{abstract}
Most climate change literature tends to downplay the gendered nature of vulnerability. At best, gender is discussed in terms of the male-female binary, seen as opposing forces rather than in varying relations of interdependency. Such construction can result in the adoption of maladaptive culturally unfit gender-blind policy and interventions. In Egypt, which is highly vulnerable to climate change, gender analysis of vulnerability is almost non-existent. This paper addresses this important research gap by asking and drawing on a rural Egyptian context 'How do the gendered relational aspects of men's and women's livelihoods in the household and community influence vulnerability to climate change?'. To answer this question, I draw on gender analysis of social relations, framed within an understanding of sustainable livelihoods. During 16 months of fieldwork, I used multiple ethnographic methods to collect data from two culturally and ethnically diverse low-income villages in Egypt. My main argument is that experiences of climate change are closely intertwined with gender and wider social relations in the household and community. These are shaped by local gendered ideologies and cultures that are embedded in conjugal relations, kinship and relationship to the environment, as compared across the two villages. In this paper, I strongly argue that vulnerability to climate change is highly gendered and therefore gender analysis should be at the heart of climate change discourses, policy and interventions.
\end{abstract}

Keywords Gender $\cdot$ Vulnerability $\cdot$ Climate change $\cdot$ Livelihoods $\cdot$ Egypt

\section{Introduction}

The literature stresses that environmental and climatic issues are constructed by people who define threats and risks according to how they experience them (Hannigan 1995; Hopkins et al. 2001; IPCC 2014). Douglas and Wildavsky (1982) note that perception of vulnerability and risk is a social process of shared threats and fears which influences and is influenced by social relations. Social and cultural factors help to identify and construct risk (Kasperson et al. 1988; Tschakert et al. 2019). 'Gender is a major axis of difference in Egyptian society' (Hopkins et al. 2001, p. 35) and thus is a major factor that affects perceptions and experiences of vulnerability to livelihood stresses, including climate-related ones.

Communicated by Debbie Ley

Mona Daoud

mona.daoud@gmail.com

1 University of East Anglia, Norwich, UK
Framed within my investigative framework, I investigate experiences of climate-related stresses on the livelihoods of men and women in the villages, drawing attention to some of the influencing gendered sociocultural dynamics. I critically draw on some elements of Cecile Jackson's (2007) creative conjugality, and Judith Butler's (1988) pressures and 'performances' of femininity and masculinity to analyse conjugal relations. Gender ideology, family structure and cultural norms affect conjugal relations that in turn affect experiences and perceptions of vulnerability and risk. In this paper, I show how these factors influence men's and women's experiences of exposure, sensitivity and adaptive capacity as elements of vulnerability (IPCC 2007, 2014).

The main research question of the paper is: How do the gendered relational aspects of men's and women's livelihoods in the household and community influence vulnerability to climate change? The paper is organized to address subquestions (Sections 3-5) emanating from the main research question. I start by discussing gendered experiences of vulnerability to climate change. I focus on exposure to rainstorms as an extreme climate event and land salinization as an incremental climate-related stress that affect my case 
study locations, and discuss how the experience of these stresses is gendered. I argue why and how these gendered processes of sensitivity to climate stresses are socially differentiated and influenced by gender ideologies of masculinity and femininity. In light of these processes, I delineate the key factors that affect adaptive capacity in my case study. These factors, applicable to other similar contexts, are essential in understanding vulnerability as well as adaptation to climate change.

\section{Gender relations, climate change and livelihoods: review and investigative framework}

Emerging gender and climate change discourse progressively recognizes that women experience climate change differently to men in terms of vulnerability and adaptive capacity (Adger 2006). Denton (2002) and Terry (2009) argue for gender vulnerability assessment that, rather than implying that women are victims, acknowledges their role as active agents of change. Arora-Jonsson (2011) and MacGregor (2010) argue for the need for a gendered analysis of vulnerability to climate change as a basis for a gender-sensitive and equitable adaptation.

The sustainable livelihoods framework (SLA) helps to integrate the social and climatic dimensions of vulnerability and adaptation through a holistic view of how people sustain their livelihoods in evolving social, political, economic and environmental contexts (Allison and Horemans 2006, Roncoli 2006). Livelihoods analysis places people at the centre of the analysis by focusing on their social and economic activities.

The SLA has its origin in literature on entitlement and food security (Sen 1982, 1999), where it acquires particular strengths for understanding social vulnerability and coping (Ellis 2006). According to Scoones (1998) and Ellis (2000), the SLA is constituted of three main components: the vulnerability context, defined as the risk factors that affect people's livelihood and survival; the livelihood context of assets, activities and processes; and the institutional context that includes an analysis of social institutions at various levels. While the livelihood approach and gender analysis have often been applied to sustainable development and environmental management, there is little literature investigating vulnerability to climate change using gender analysis of masculinity and femininity that shape gender relations that in turn affect vulnerability of the household and community. This is the main contribution of this paper to the field of gender and climate change.

To operationalize my research question, I mainly use an adapted sustainable livelihoods framework, which integrates the vulnerability, the livelihood and the institutional contexts.
I focus on the household in the institutional context, which puts intra-household gender relations at the heart of the analysis. Gender analysis of vulnerability of livelihoods to climate-related stresses aims to transcend the superficial representation of gender roles adopted in mainstream climate change and gender literature and focus on gendered cultures and relationships in people's livelihoods.

\section{Vulnerability context}

The Fourth Assessment Report of the United Nations Intergovernmental Panel on Climate Change (IPCC 2007) conceptualizes vulnerability as a function of both the nature of the biophysical climate change impacts and the state of social systems. IPCC (2007) defines vulnerability as a function of exposure, sensitivity and adaptive capacity. The Fifth Assessment Report (IPCC 2014) further adds the concept of risk of climate hazards - adopted from the disaster risk reduction literature - to the concept of vulnerability.

The term 'vulnerability' is defined, used and conceptualized differently in the climate change, entitlements theory and disaster risk reduction literature (Adger 2006; Füssel and Klein 2006; Tucker et al. 2015). A meaningful consideration of the concept depends on the context and purpose of the vulnerability assessment. Adger (2006), Füssel (2007) and O'Brien et al. (2009) identify two distinctive epistemological paradigms in vulnerability research that are used according to the objective in question. The first, referred to as outcome vulnerability, has grown out of various risk-hazard and impact frameworks (Füssel and Klein 2006). It focuses on vulnerability to environmental impacts and then adds on social parameters. The second, contextual vulnerability, originates from the literature on entitlement and livelihoods frameworks rooted in social systems (Ellis 2006; Sen 1982, 1999). It focuses on the variation and dynamics of vulnerability within and between social groups, emphasizing aspects of inequality and distribution (Adger 2006).

Petra Tschakert and others (Tschakert et al. 2019) nuance the concept of vulnerability by examining climate change and loss through value- and place-based approaches that are sensitive to the nature of people's lives. Tschakert and others (Tschakert et al. 2017) further foreground personal stories as an essential mean to humanize and understand vulnerability. I situate my analysis within this understanding of lived experiences and how people perceive and experience vulnerability.

I adopt a social contextual definition of vulnerability that arises from the underlying social conditions and changing characteristics of people, households or communities in terms of their susceptibility and capacity to anticipate and cope with exposure to climate-related stresses. This study focuses on the gendered relational nature of perceptions and experiences of vulnerability to climate-related stresses against the backdrop of socio-economic livelihood stresses within and beyond the 
household. It relates gender norms and intra-household gender relations to social vulnerability within people's livelihood context.

\section{Livelihood context: assets, activities and processes}

Researchers privilege different indicators or factors of adaptive capacity which include different forms of assets framed in different ways (Adger et al. 2009). These factors are mediated by sociocultural characteristics and relations manifesting through social institutions (Kabeer 1999). I argue in line with Tschakert and Machado (2012) that the most significant gaps in climate change research concern the difficulty of addressing the social norms and practices that create unequal access to and control over households and communities' tangible and intangible assets, thereby restricting adaptive capacity.

The livelihood assets and/or forms of capital are generally divided into natural, financial, physical, human and social assets (Scoones 1998; Sen 1999). I add cultural and symbolic capital, as developed by Pierre Bourdieu (1986), as indispensable assets to people's livelihoods and their relations. Access to these forms of capital, which I study in this paper, is socially differentiated at the individual/intra-household level.

\section{Institutional context: Gender relations}

Within the institutional context of people's livelihoods, I focus on gender relations as the core of my study. I adopt Naila Kabeer's (1994) social relations approach, which takes a socialist feminist philosophy to gender analysis and considers gender relations at several levels of analysis and identities such as age, class and ethnicity. Framed within this approach, I critically draw on elements of Jackson's (2007) creative conjugality to analyse intra-household conjugal relations and how they influence men's and women's experiences of vulnerability. I also use Butler's (1988) feminist theory of gender as a social performative construction reproduced by social, cultural and ideological norms and pressures of femininity and masculinity, in analysing the change in gender social relations and in turn, vulnerability to climate change.

Detailed studies of livelihood strategies have drawn attention to the fact that most people, particularly in the developing world, maintain their livelihoods in their surrounding social and natural environment as members of a household rather than as autonomous individuals (Chant 1991). This is particularly true in Egypt, where the domestic unit is at the centre of social life, the household is based on family and/or kinship, and the interdependence of family as household members is emphasized (Hoodfar 1997; Singerman 1996). In an uncertain world, membership of household or kin-based groups is a principal means of access to resources and livelihood security (Gonzalez de la Rocha 1994; Singerman 1996). On the other hand, vulnerability and lack of resources influence the ties between members of the household both positively and negatively.

The household/family remains important as a unit of analysis, but it is important to look within the household to investigate intra-household relations, and conceptualize human agency, experience and culture (Abu-Lughod 1986; Jackson 2007). This is why I complement Kabeer's social gender relations framework (2013) with an analysis of intra-household relations (Butler 1988; Jackson 2007). I explicitly acknowledge the importance of recognizing both separate and shared interests within the household. This is critical to understanding vulnerability to risks in people's livelihoods where 'the character of conjugality and other household relations mediate behaviour in relation to risk' (Jackson 2007, p. 115).

This combined conceptual framework shows how vulnerability to climate-related impacts on livelihoods is mediated by gender relations. The framework investigates the mechanisms and missing links between gender relations and vulnerability to climate change, particularly in the context of marginal livelihoods, as exemplified in my case study of two villages in Egypt.

\section{Research design: Case study}

To research the interlinkages between gender relations and vulnerability to climate change, I employ a predominantly qualitative comparative case study methodology with some quantitative analysis. The focus on qualitative methods and analysis allowed me to explore the complexities of gender relations and how they affect and are affected by vulnerability to climate-related stresses (Daoud 2016). By examining the context and mechanisms linking gender and climate change, insights from the study can draw useful implications for groups and individuals in similar settings.

The two cases I study are the Nubians in Aswan in Egypt's Nile valley as a unique case, because of their history, culture and ethnicity, which is different from the representative (Yin 2004) or 'exemplifying case' (Bryman 2012, p. 70) of Maryut community in Alexandria in the Nile Delta that is considered 'mainstream' Egyptians. This helps to nuance the discourse and highlight the key role of social relations and institutions in shaping experiences of vulnerability to climate change. The criteria of choice for the two sites were based on elements of similar livelihood conditions, and exposure to local climate stresses with differing ethnicity, family structure and sociocultural norms that shape gender relations (Table 1).

The Nubian community, as a distinct cultural group in Egypt, most strongly reflects the kinship cohesion and support system that feature in most Middle Eastern societies (Jennings 1995). On the other hand, people in Maryut indicated that the increasing movement of the population of villages on the 
Table 1 Criteria of selection of the case studies

\begin{tabular}{|c|c|c|}
\hline Selection criteria & Maryut village in Alexandria & Nubian village in Aswan \\
\hline Climate impacts and risks & $\begin{array}{l}\text { Climate extremes, precipitation and seasonal } \\
\text { changes monitored traditionally through following } \\
\text { the rainstorms Coptic calendar } \\
\text { Indirect impacts of sea level rise such as land salinization } \\
\text { and rise of the water table as well as possible relocation } \\
\text { of neighbouring communities on the coastline }\end{array}$ & $\begin{array}{l}\text { Climate extremes, precipitation and seasonal changes } \\
\text { monitored traditionally through following the floods } \\
\text { Pharonic calendar } \\
\text { Historically Nile flooding before the construction of the } \\
\text { Aswan High Dam that caused the relocation of more } \\
\text { than 120,000 Nubians to South Aswan } \\
\text { Indirect impacts of Aswan dam and Nile shore flooding } \\
\text { such as land degradation and rise of the water table }\end{array}$ \\
\hline Livelihoods & $\begin{array}{l}\text { Agriculture (fruits and wheat) } \\
\text { Fishing in lake Maryut and the Mediterranean Sea } \\
\text { Tourism } \\
\text { Migration to work in big cities in Egypt } \\
\text { or in the Gulf countries }\end{array}$ & $\begin{array}{l}\text { Agriculture (sugarcane and wheat) } \\
\text { Fishing in lake Nasser } \\
\text { Tourism } \\
\text { Migration to work in big cities in Egypt } \\
\text { or in the Gulf countries }\end{array}$ \\
\hline Community characteristics & $\begin{array}{l}\text { Mainstream Egyptian ethnicity } \\
\text { Mostly Muslims } \\
\text { Patriarchal patrilineal community, typical } \\
\text { in Egyptian society } \\
\text { Social networks are mostly based on neighbours and } \\
\text { friends that, as perceived by people in the village, are less } \\
\text { dependable than those based on kin }\end{array}$ & $\begin{array}{l}\text { Nubians are from a distinct ethnographic and cultural } \\
\text { background and are more marginalized as an ethnic minority } \\
\text { Muslims } \\
\text { Distinct gender perspectives starting from 'warrior-queens' } \\
\text { in Pharonic times, to matrilineal matrilocal societies } \\
\text { influenced by African culture, higher female to male } \\
\text { ratio and higher rate of girls' education } \\
\text { Nubian community based on common ancestry, kinship } \\
\text { and extended families }\end{array}$ \\
\hline
\end{tabular}

outskirts of big cities has resulted in culturally diverse communities of people from different parts of Egypt. They do not share the same social and cultural customs, which weakens the cohesion of these social networks. Hopkins et al. (2001) note this perception of lack of cooperation in Egypt, where $93 \%$ of their respondents at four Egyptian sites in the north felt that people are becoming less cooperative and that family support is the only remaining form of reliable cooperation. In Nubia, the perception tended to be different, with almost all respondents describing their village as a 'big family'.

Living in the research communities for 16 months (20132015) was extremely valuable in experiencing first-hand the

Table 2 Research phases and methods

\begin{tabular}{|c|c|c|}
\hline Fieldwork phase & Method & Details \\
\hline $\begin{array}{l}\text { Scoping and } \\
\text { preliminary phases: }\end{array}$ & $\begin{array}{l}\text { Sample framing and key } \\
\text { informant interviews }\end{array}$ & $\begin{array}{l}\text { Village informants in and outside the villages (village sheikhs, school teachers, staff at social } \\
\text { services, municipalities, etc.) }\end{array}$ \\
\hline \multirow[t]{2}{*}{$\begin{array}{l}\text { Getting acquainted and } \\
\text { building trust }\end{array}$} & $\begin{array}{l}\text { Secondary documentary } \\
\text { analysis }\end{array}$ & Relying on local ethnographies such as Jennings $(1995,2009)$ and Hoodfar (1997) \\
\hline & Participatory rural analysis & Two separate groups of $10-15$ men and $10-15$ women in each village \\
\hline \multirow[t]{4}{*}{ Data collection } & $\begin{array}{l}\text { Semi-structured village } \\
\text { interviews }\end{array}$ & $\begin{array}{l}25 \text { couples (one per household) and other younger and/or older members of households in each } \\
\text { village ( } n=144) \text { to assess individual perceptions and accounts of gender relations, climate } \\
\text { change and livelihoods }\end{array}$ \\
\hline & $\begin{array}{l}\text { Semi-structured policy } \\
\text { interviews }\end{array}$ & $\begin{array}{l}10 \text { interviews with experts working in the fields of development and climate change to provide } \\
\text { expert discourse and data }\end{array}$ \\
\hline & Life histories & $\begin{array}{l}10 \text { older interviewees with whom I built a close rapport to assess and trace change and } \\
\text { perceptions of change through time and place }\end{array}$ \\
\hline & Focus groups & $\begin{array}{l}6 \text { gender-segregated focus groups ( } 3 \text { for men and } 3 \text { for women) of } 7-10 \text { men and } 7-10 \text { women } \\
\text { in each village to elicit normative discourses in the villages and highlight the gap between } \\
\text { ideology and actual practice }\end{array}$ \\
\hline $\begin{array}{l}\text { Reflection and } \\
\text { feedback }\end{array}$ & $\begin{array}{l}\text { Reflection and feedback on } \\
\text { collected data }\end{array}$ & $\begin{array}{l}\text { Reflection and feedback on preliminary analysis from the participants involved and generally } \\
\text { from people in the villages }\end{array}$ \\
\hline All phases & Participant observation & To provide tacit and deeper insights into everyday lives, relations and interactions in the villages \\
\hline
\end{tabular}


values, perceptions, attitudes and actions of people in the villages (Daoud 2016). I employed multiple methods to understand the case study setting, as detailed in Table 2 .

\section{Gendered variation in experiences of vulnerability to climate-related stresses and shocks that affect people's livelihoods}

In this section, I address the question: What are the main climate-related stresses and shocks that men and women experience and are expected to experience? My evidence strongly indicates that climate-related stresses and shocks have a serious impact on people's livelihoods at my case study locations. In my interviews, I did not force any direction on people; however, all the women and men in both villages, with no exceptions, brought up climate or environmental stresses or shocks, including changes in temperature, seasons and rainfall patterns, as threats to their resource-dependent livelihoods.

Most men and women in each village agreed on the same climate-related stresses and risks, but their ranking was different. Land salinization and rainstorms figured as priority stresses in Maryut, and loss of land fertility, water stresses, increased temperature and the number of hot days and rainstorms were priorities in Nubia. These priorities are consistent with policy interview responses and national environmental reports in Egypt (e.g. EEAA 2016, 2017), which give high priority to agriculture and water issues.

There is variation of ranking of threats by locality and gender. While the identified threats in both villages were similar, their ranking is different. The major difference is destructive rainfall, ranking higher in Maryut, which is more exposed to it. Water issues and connection to the Nile rank higher in Nubia due to its proximity to the Nile and the historical connection between Nubian livelihoods and the river. A noticeable outlier is the high ranking of Nubian women of the fear of Nile water shortage. When asked about such high ranking of a threat that is not directly 'seen', the interviewed Nubian women expressed that it is a fear that they 'get' from Egyptian mass media, particularly television talk shows that promulgate this fear. An explanation of this phenomenon is that women in Nubia are more exposed to television than men, as indicated in the interviews with men and women in Nubia. Thus, they reflect the fear of the dominant national discourse of presenting Nile water shortage as a national security issue that heightens popular fear of climate impacts on Nile water availability as well as other factors affecting it such as the erection of the Grand Ethiopian Renaissance Dam.

There are patterns in the ranking of threats by gender, with parallels and contrasts. There are striking similarities in identifying climatic or environmental changes and their impacts on individual and family livelihoods. This observation was also found by Hopkins et al. (2001) when studying perceptions of environmental change and pollution in Egypt. The differences are mainly reflected in the ranking and interpretation of threats and their impacts. Women expressed more concern about the shifting baselines of environmental change, weather patterns and the increased intensity and frequency of weather events as they diverge from the traditional calendar. Men expressed more awareness of the incremental changes in land fertility and crop patterns. These differences and the ranking of threats are related to gender roles in the villages, with men ranking threats that directly affect agriculture like land salinity and access to farming inputs higher. Women ranked threats that affect daily life and social interactions in the villages higher. However, these differences are not clear-cut because women and men share household and livelihood experiences; the ranking of threats reflects their individual priorities. Women also tended to perceive and express issues in more personal terms, while men tended to see and express them in more pragmatic, financial and technological terms.

\section{Extreme events: Nightmares of rainstorms and floods}

In individual and group interviews, men and women prioritized extreme rainfall and flood events as a major threat due to their extreme unexpected and feared nature and the extent of their destruction. In general, the villagers in the two villages perceive these extreme events to be less predictable and more frequent today than 30 years ago. These experiences of vulnerability are highly influenced by gender, as reflected in the group interviews and analysed in the 'Gendered experiences of vulnerability: Gender norms as discursive tools' section. This finding is corroborated by similar evidence in Terry's (2011) study where gender was a main factor influencing the experiences and perceptions of vulnerability to rainstorms in Ugandan villages.

Rainstorms and floods affected the villages in 2009, 2012, 2013 and 2014. In the group discussions in the two villages, I asked the gender-segregated groups about the worst environmental shock they had experienced. In Maryut, $75 \%$ of men and women chose the 2009 rainstorms as the most 'frightening' weather event they had experienced. In Nubia, $90 \%$ of men and $85 \%$ of women chose the 2014 floods. The floods of March 2014 in Aswan and other governorates in Upper Egypt (e.g. Sohag and Qena) resulted in the deaths of 9 people and a large number of livestock, the loss of 3000 feddans of cultivated land and the destruction of over 200 rural households (Cabinet of Ministers 2014).

\section{'Our land will be barren': Loss of soil fertility, erosion and salinization}

Loss of soil fertility due to salinization, erosion, extreme temperatures and loss of sediment now trapped behind the High Dam was ranked as a major stress by the villagers. As farmers, 
land is key to livelihoods in the villages. Loss of soil fertility was a stress recognized by both men and women in the villages. However, its ranking and interpretation as a major stress was much more substantial for men who, in their acquired gender roles, work the land. The women generally do not work on the land. They are mostly in charge of livestock, chicken and pigeons and of processing and/or selling the crops produced.

People's accounts also reflect fear of the loss of their land's fertility and productivity due to climatic conditions. This risk is real, but, as highlighted by Hannigan (1995) and White (1988), it is also socially constructed with the people defining the threat, the level of fear it engenders and its importance in their livelihoods. Adverse climatic conditions compound other stresses such as the unavailability of fertilizers, the lack of social welfare for farmers and the lack of government support that contribute to their vulnerability.

Policy interviews with government officials confirmed these observations. They highlighted the fact that soil fertility problems and salinization feature prominently in official discourse. However, the policy accounts reveal minimal concern or attention to the gendered nature of these experiences of vulnerability.

\section{Gendered experiences of vulnerability: Gender norms as discursive tools}

In this section, I explore vulnerability more closely by addressing the question: how do gender relations affect livelihood conditions and vulnerability to climate change? I analyse how the men's and women's experiences of vulnerability in the villages are influenced by their gendered positions and ideology. I argue that gender ideology that creates pressures on both men and women increase their vulnerability.

\section{Pressures on masculinity}

Local gender ideology and norms, and livelihood stresses and shocks, including climate-related ones, increase men's vulnerability in the villages. I discuss man's traditional role as the provider for the household as a main pressure on masculinity (as well as on femininity as will be discussed in the next subsection). This pressure is part of a wider traditional and historical norm in the Middle East (Tadros 2010). I analyse it in terms of people's livelihoods and draw out its implications for adaptive capacity.

\section{Man as the provider}

According to Islamic and traditional mores in Egypt, men are held responsible for providing for their families. Islam gives the wife the unconditional right to financial support from her husband, including her basic needs (shelter, food and clothing) as well as the needs of the home and the children, even when she is employed and has her own substantial income (Ahmed 1992). The wife is solely entitled to her own income to spend as she chooses, with no financial obligations to her or her family's basic needs. However, this does not automatically imply that women spend their wages on themselves or their leisure freely, but it gives them power and autonomy about how they spend their income.

As elicited in the interviews, men see a direct link between their masculinity and their role as provider in marriage. Any deviation from this norm threatens their sense of masculinity and adequacy as the husband and head of the household. With climate-related stresses on their livelihoods and the rising need for cash, many men fail to fulfil their financial obligation to their families and try to find ways to limit it. Some men, mostly in Maryut, regretfully acknowledged that with the environmental stresses on their livelihoods and their decreasing income, they were failing to keep up the traditional household customs. Many older women openly acknowledged that this family arrangement causes family problems, but only a few of the younger women welcomed the change. Some women whose husbands cannot provide for them in both villages commonly complained of them as 'lazy and selfish'. This was paralleled by the men's complaint about 'demanding unsupportive' wives. These attitudes and behaviours cause conjugal conflicts.

Under these obligations, men depict themselves as pressured by the social and cultural responsibility for providing for the household. This depiction of the pressure to provide was reflected in many accounts given in individual and group interviews in the villages. These accounts exemplify the typical masculine discourse on the gendered dimensions of vulnerability. These accounts also signify how gender roles are accepted and normatively maintained, even in changing conditions. While some studies in rural sub-Saharan Africa indicate that the responsibility for household provisioning is transferred mainly to men in hard times (Jackson 2007; Terry 2011), in Muslim rural communities such as in Egypt and the rest of the Middle East, it is always men's social and religious obligation whether they are able to fulfil it or not. This puts constant pressure on them that increases in times of livelihood stress and need.

Increasing exposure to climate stresses and shocks exacerbate the underlying pressures on men's livelihoods, constraining their ability to provide for the household and fulfil their masculine duty to the household and community. Women use 'the man as provider' discourse to make their husbands fulfil their provisioning responsibilities. This analysis is corroborated by Jackson (2007) who argues that legitimizing their dependence on their husbands can be a useful discursive tool that allows married women to benefit from men's provisioning role. In households with severely 
asymmetric decision-making power, a multitude of examples of 'everyday forms of conjugal resistance' (Jackson 2007, p. 2) revolve around this discourse. Most women in the villages told me about acts of resistance including hiding their income, shaming their husbands if they cannot fully provide for the household and using their skills at processing spices (in Nubia) or selling fish (in Maryut) to bargain for a bigger household allowance.

The ethnographic literature adds weight to these perceptions of men's conjugal vulnerability. Abu-Lughod (1986), Hoodfar (1997) and Jennings $(1995,2009)$ argue that men in low-income traditional domestic-centred communities in Egypt gain social, cultural and symbolic status by fulfilling their role of providing for their families and households. This status that reflects on the respectability of their household and families is their main source of masculine status and prestige. With increasing climate and livelihood stresses, men fail to fulfil that 'masculine' role which puts pressure on them and creates conjugal conflicts that in turn increase their vulnerability.

\section{Pressures on femininity}

In light of the prevailing gender norms in the villages, women face many pressures that increase their vulnerability and that of their household. The most prominent pressures, revealed in the case study, result from the social constraints on women's engagement in off-farm livelihood activities outside the house and village, whether in the petty trading of fish, fruit and vegetables or any other informal income-earning activity.

\section{Conjugal contestations over women's livelihood activities}

With increasing livelihood stresses, including climate-related ones, wives are obliged to maintain their families' livelihoods by finding employment (in Maryut), seeking their families' assistance (in Nubia) or finding ways to ensure that their husbands fulfil their obligation to the household. However, traditional gender ideology prevents women working outside the village when they can engage in informal activities such as processing spices, handicrafts or raising cattle, which are seen as an extension of their domestic work. It seems that wives earning cash may be viewed as a transgression of male authority and the husband's pivotal responsibility for providing for the household. From another point of view, some women also fear devaluing their domestic role and adding more demands on their energy and time.

The problem is not only about the threat of women earning money. Men do not have a problem with women earning money from informal income-earning activities that they do in the house or the village. This type of in-house productive work is considered domestic work and does not challenge the traditional gender norms and status quo. Men's objections to their wives working outside the village may also emanate from concern about them congregating with men in public places such as on public transport and in markets in the city centres.

Men's objection to their wives working is not only framed as a threat to their authority, role or honour but also sometimes justified in terms of the costs involved. The low wages that village women can earn make men and women question the cost of employment that would not contribute much to the household. However in Maryut, due to increasing livelihood stresses, generally if the women's job is critical to the family's livelihood, the husband agrees and even encourages her to work, driven by need and not by a change in social attitude or gender ideology. In similar stressful conditions, most women in Nubia work from home due to the long distance from the village to the city centre, tighter family traditions and extended household pooling.

In other cases, conjugal conflict arises over the control of the woman's income, which is not in line with Islamic mores of giving the wife complete control over her income. On the other hand, women are conscious that environmental and socio-economic stresses are gradually decreasing men's involvement in the daily life of the household. With the increasing need for cash and livelihood diversification, women who are not supported by kin are obliged to enter the labour market. They adopt strategies to resist this reversal of the gender roles by appealing to traditional ideology to secure their husbands' commitment to the household, pressuring them to provide their basic needs such as food, shelter and clothing. These strategies include resisting silently, resisting vocally by arguing or involving a neighbour or family member to argue for them and resisting actively by leaving their jobs to oblige their husbands to contribute under the pretence that they need to care for their children. Married women communally and openly discuss different strategies for manipulating their husbands into providing for the household. These bargaining strategies, as analysed by Agarwal (1997) and Jackson (2007), constitute discursive tactics to emphasize the husbands' provisioning responsibility.

These manipulation strategies presuppose a necessity to view the needs and rights of the under-privileged - women in this context - within the existing social and material constraints of realizing them (Kabeer et al. 2013). How do the underprivileged penetrate, manipulate and bargain with the ideological norm set by the privileged? Kandiyoti (1998, p. 147) calls this 'bargaining with patriarchy' and it suggests agency woven into 'the limits of the culturally conceivable'. However, this does not in any way deny the fact that there is a need and even an obligation to question these constraints and strive for long-term social change to modify them.

The constraints on women's income earning increase their vulnerability to climate-related stresses, among other livelihood stresses. In short, I argue that with the existing gender roles and ideology, livelihood stresses put greater pressure on 
men and women and on conjugal gender relations. Threatened gender relations may increase vulnerability and hinder the adaptive capacity of households, and the vicious cycle continues.

Hence, there are unequal gendered authority relations, whereas the issue is not whether there is more pressure on men or women, but how these pressures on masculinity and femininity affect gendered relations that in turn increase vulnerability. This link is mediated by several gendered factors that play a role in shaping vulnerability and ability to adapt (Carr and Thompson 2014). Situating gender relations within these other social relations and norms is essential in understanding social vulnerability.

\section{Gendered factors of adaptive capacity}

In this section, I address the question: Through a gender analysis lens of intra-household relations, what shapes the adaptive capacity of men and women in the household and community? From my data, income-earning prospects is not a defining factor in household bargaining or adaptive capacity. In general, women in Maryut earn more money than women in Nubia, but their husbands generally control both their money and the income to be spent on the household. They participate actively in family income earning but not in budgeting or expenditure. My data on actual household expenditure reveal that even with the minimal number of income-earning women, household preferences in Nubia correlate more closely with the women's preferences. In Maryut, where $82 \%$ of the women in my sample worked-more than the national figure of $23.4 \%$ (CAPMAS 2013) — household decisions in male-headed households reflected men's preferences. I found that women's visible work does not automatically translate into their empowerment. I argue that the relaxation of patriarchy, or, more simply put, the diminishing provision and protection roles of men due to economic hardship, necessitating women to take low-paying and time-consuming jobs outside the home, does not necessarily lead to the women's empowerment or improved capacity to adapt, which requires a change to societal gender norms. In critique of Sen's (1999) key concept on the perception of value and fallback position based on women's 'productive work', I argue that women's bargaining position and power seem to correlate with other factors such as their personality, family support, age, life course and personal characteristics and relationships with spouses, families and wider society, rather than to their access to income.

Cross-cultural studies indicate that household bargaining is affected by contextual cultural practices, the family life cycle and the nature of livelihood activities (Agarwal 1997; Jackson 2007; Pahl 1989; Rao 2014). However, each factor has a different weight depending on the specific norms of the community and even the household in question.

\section{Family life cycle of the marriage}

The family life cycle or life course of the marriage is linked to the ages of the spouses and the number of years they have been married. In traditional communities, women gain agency and voice with age, particularly after menopause, when they acquire more respect and freedom (Rao 2014). From my fieldwork observations and other ethnographic studies (Hoodfar 1997; Jennings 1995), this correlation is more prevalent in Nubian than in Delta communities, and plays a greater role in Nubia, where women in the later stages of the family cycle have more authority and power. This is related to the long history of Nubian warrior queens and female spiritual figures.

A family passes through several stages, from marriage to the birth of children, the children leaving home, and its dissolution or extension (within the extended family structure). The family cycle analysis considers the family as a process of gender relations over time rather than a static unit. It assumes that men and women live through different family life cycle stages in their families and households which have different types of organization and structure (Hareven 1974). This dynamic is captured in individual and life history interviews which provide a 'longitudinal tracing' (Hareven 1974, p. 326) rather than a cross-sectional snapshot.

I categorize my data into four categories according to the length of the marriage: $1-10 ; 11-20 ; 21-30$; and more than 30 years. From people's accounts of their perceived ability to cope with changing intra-household relations, and thus consequently adapt to livelihood stresses including environmental change, along with my observations of their actual ability to adapt, I arrived at the following results, which are largely similar in both villages, with some differences. Couples married for 21-30 years were more able to cope, followed by those with 11-20 years of marriage. At these stages of the family life cycle, the marriage has passed through the first rocky years, children have been born and the family is established, and the couple has reached a stable phase in conjugal relations (e.g. bargaining to cope with stresses). At $21-$ 30 years, the marriage is more stable due to the added support of young adult children who can help their families in such activities as farming, house construction and household activities. These first two categories are similar in both villages. The marriage of 1-10 years comes third in Nubia and fourth in Maryut, while the marriage of over 30 years comes third in Maryut and a close fourth in Nubia. This may be due to the fact that couples are supported in the early years of marriage by extended family, which is not generally the case for the nuclear families in Maryut. Beyond 30 years of marriage, there is less adaptive capacity due to the age and decreased productive capacity of the married couple; another reason is 
that at this stage of the marriage, the children leave their natal households to establish their own homes with the economic support of their parents.

\section{Marital and fertility status}

Marital and fertility status is not only a source of financial capital; it also brings social, symbolic and cultural capital to both men and women in the form of prestige and acceptability in the community. Single men and women beyond the age of 25 (as an average expressed by the residents in the two villages) are considered outcasts in the community and are thus more vulnerable than married men and women at their age. Having children, particularly sons, is also considered social and economic capital in both villages as it gives prestige in the community and improves the household income, as the children assist with the household expenses.

Marital and fertility status strongly affect men's and women's social and cultural capital in the community, in turn impacting on their economic prospects and adaptive capacity. In 'The Forms of Capital', Pierre Bourdieu (1986) explains this link between cultural, social and economic capital, where cultural and social capital may be convertible into economic capital depending on societal conditions, and how people internalize the value of the different forms of asset. Marital status in the villages has a stronger influence on women's status but also affects men at a later age. Fertility and the preference for boys seem to affect both wives and husbands equally. Many women and men see their fertility as the ultimate way of dealing with economic insecurity, for example by having many sons, who are expected to support them.

The family life cycle and marital and fertility status are gendered factors of adaptive capacity that affect the vulnerability of men and women and their families/households in the village communities. Next, I focus specifically on kinship, which is the main difference between the two villages with their different family structures: Maryut, which consists mostly of nuclear families and Nubia, which comprises large extended families of a single ethnicity who intermarry in a mostly matrilocal setting.

\section{Family structure and kinship}

In this section, I show how family structure and kinship, crosscut by the above factors of adaptive capacity, shape individual, household and community adaptive capacity. In Egypt in general, society centres on the family at the heart of social organization and structure, which gives special significance to kindred. The family is considered the primary risk-sharing social unit at the root of household livelihoods and kinship networks (Fafchamps 2003). As the main difference between the villages, kinship is the most visible factor differentiating their adaptive capacity. I relate the link between gender relations and vulnerability to underlying context-specific kinship and family structures that affect adaptive capacity (Cannon 2002; Hemmati and Röhr 2007).

The support of a woman's kin appears to be one of the most important factors influencing men's attitudes to their wives' household responsibilities and shared decision-making. This is also observed by Hoodfar (1997) in a study of poor neighbourhoods in Cairo. Nubian women generally have control of the household financial budgeting and retain full control of their own income from income-earning activities in the household (e.g. from sales of handicrafts and processed spices). Some of the most content wives of my sample were from Nubia. Men in Maryut are generally (as reported by the women) less sensitive to the needs of their wives than those in Nubia. This, as explained by the women in both villages, may be due to the extended family structure that supports and protects women's interests as the 'queen of the house'.

This analysis leans towards the hypothesis that women (in Nubia) who are supported/protected by their natal extended family are less vulnerable than those (in Maryut) with a more nuclear family setting. This reflects their better relations with their husbands, who are accountable to their wife's family and kin, and in turn contributes to better household adaptive capacity.

Household bargaining is situated within the context of the existing system of gendered forms of kinship and family structure that define the nature of the conjugal contract. The Nubian natal kin support system strengthens women's bargaining power and fallback position and endorses their agency within the dominant gender ideologies and orders. This in turn affects gender relations within and beyond the household, and the adaptive capacity of the household and its members. Better gender relations result in better adaptive capacity, mitigating vulnerability to climate and livelihood stresses.

Family structure also affects the adaptive capacity of individuals and the community in other ways, such as in pooling income. In general, higher family income was found among the extended families in Nubia due to the adult family members pooling their income. The extended family structure provides social and economic support to men and women and their households and community, enhancing their ability to adapt. This is why my findings suggest that Nubia, with its extended family structure, has greater capacity to adapt to climate and livelihood stresses than Maryut, as corroborated by Whitehead and Kabeer's (2001) argument that the extended household communities that characterize West African societies provide protection against livelihood stresses.

\section{Conclusion}

In this paper, I argue that the livelihoods of men and women are perceived by villagers as vulnerable to climate-related stresses, among other livelihood stresses, in my case-study 
villages. The villagers perceive rainstorms as one of the most damaging climate impacts on the villages. Given that land underpins the livelihoods and cultural life of rural villages, climate-related incremental stresses such as land salinization, decreased land fertility and increasing temperatures that affect crops and demand for water are also imminent threats that affect individual and household livelihoods. If projections about these climate stresses are correct, the expected impacts are likely to intensify experiences of vulnerability and poverty in the people's daily life in both villages.

Climate-related stresses and shocks interact with the sociocultural norms and values that shape household gender relations and result in culturally constructed gender-specific vulnerability. Marriage remains the main arena within which social relations in general and gender relations in particular manifest. The institution of marriage and gender ideology provide a framework for household decision-making and bargaining that affect perceptions and experiences of individual and household vulnerability.

Asymmetric gender relations and gender ideology are maintained or reproduced in the process of household bargaining. Gender norms that shape gender roles and relations, household decision-making, mobility and access to and the control of different types of assets/capital make vulnerability a gendered experience at the individual, household and community levels. I argue that in light of the persisting gender norms in Egypt, increasing vulnerability can negatively affect gender relations in the household in several ways. It leads to a decline in married women's bargaining power and fallback position, a trend observed in rural Africa (Bryceson 2002; Terry 2011). It also increases the pressure on men who cannot fulfil their main gender role of provider for their household. Such pressures on masculinity and femininity skew gender relations and in turn increase vulnerability. This vicious cycle constitutes a serious livelihood issue because of the negative socio-economic and relational impact on men's and women's livelihoods and ability to adapt.

Gender norms create unequal gender relations that exert pressures on masculinity and femininity that in turn increase vulnerability to climate and livelihood stresses. This link is mediated by gendered factors that play a role in shaping adaptive capacity. These factors are shaped and reshaped by gender norms and relations. The study of gender relations focuses not only on men and women in their separate worlds but also on the family, the basic unit that frames and affects men and women livelihoods, and its structure and cycle. Gender analysis in this context encompasses other factors of adaptive capacity that influence and are influenced by household bargaining, such as the family life cycle, marital and fertility status, and forms of kinship and family structure. Situating gender relations within these wider social relations and norms is essential in understanding social vulnerability. Drawing on feminist theories helps deepen gender analysis of vulnerability to inform theoretical understanding of gendered vulnerability to climate change, beyond the geographical scope of Egypt. Analysing social vulnerability through the lens of gender analysis is by no means marginal: it should be at the heart of understanding vulnerability to climate stresses and should be an integral part of climate change discourses, policy and adaptation plans.

Open Access This article is licensed under a Creative Commons Attribution 4.0 International License, which permits use, sharing, adaptation, distribution and reproduction in any medium or format, as long as you give appropriate credit to the original author(s) and the source, provide a link to the Creative Commons licence, and indicate if changes were made. The images or other third party material in this article are included in the article's Creative Commons licence, unless indicated otherwise in a credit line to the material. If material is not included in the article's Creative Commons licence and your intended use is not permitted by statutory regulation or exceeds the permitted use, you will need to obtain permission directly from the copyright holder. To view a copy of this licence, visit http://creativecommons.org/licenses/by/4.0/.

\section{References}

Abu-Lughod L (1986) Veiled sentiments: honor and poetry in a Bedouin society. University of California Press, California

Adger N (2006) Vulnerability. Glob Environ Chang 16:268-281. https:// doi.org/10.1016/j.gloenvcha.2006.02.006

Adger N, Lorenzoni I, O'Brien K (2009) Adapting to climate change: thresholds, values, governance. Cambridge University Press, Cambridge

Agarwal B (1997) Bargaining and gender relations: within and beyond the household. Fem Econ 3:1-51. https://doi.org/10.1080/ 135457097338799

Ahmed L (1992) Women and gender in Islam. Yale University Press, New Haven

Allison E, Horemans B (2006) Putting the principles of the sustainable livelihoods approach into fisheries development policy and practice. Mar Policy 30:757-766. https://doi.org/10.1016/j.marpol.2006.02.001

Arora-Jonsson S (2011) Virtue and vulnerability: discourses on women, gender and climate change. Glob Environ Chang 21:744-751. https://doi.org/10.1016/j.gloenvcha.2011.01.005

Bourdieu P (1986) The forms of capital. In: Richardson J (ed) Handbook of theory and research for the sociology of education. Greenwood, New York

Bryceson D (2002) The scramble in Africa: reorienting rural livelihoods. World Dev 30:725-739. https://doi.org/10.1016/S0305-750X(02) 00006-2

Bryman A (2012) Social research methods. Oxford University Press, Oxford. https://doi.org/10.1016/S0305-750X(02)00006-2

Butler J (1988) Performative acts and gender constitution: an essay in phenomenology and feminist theory. Theatr J 40:519-531. https:// doi.org/10.2307/3207893

Cabinet of Ministers (2014) Cabinet of Ministers Rainstorms Press release March 2014. Cairo, Egyptian Cabinet of Ministers

Cannon T (2002) Gender and climate hazards in Bangladesh. Gend Dev 10:45-50. https://doi.org/10.1080/13552070215906

CAPMAS (2013) The state of Egyptian children and women. Cairo, CAPMAS and UNICEF

Carr E, Thompson M (2014) Gender and climate change adaptation in agrarian settings: current thinking, new directions, and research frontiers. Geogr Compass 8:182-197. https://doi.org/10.1111/gec3.12121 
Chant S (1991) Women and survival in Mexican cities: perspectives on gender, labour markets, and low-income households. Manchester University Press, Manchester

Daoud M (2016) Using fieldwork to explore the linkages between gendered livelihoods and adaptation to climate change: insights and challenges. Sage Research Methods Cases. SAGE Publications, Ltd. doi: https://doi.org/10.4135/978144627305015595364

Denton F (2002) Climate change vulnerability, why does gender matter? In: Masika R (ed) Gender, development and climate change. Oxfam Publications, Oxford

Douglas M, Wildavsky A (1982) Risk and culture: an essay on the selection of technical and environmental dangers. University of California Press, Berkeley

EEAA (2016) Egypt Third National Communication to the United Nations Framework Convention on Climate Change (UNFCCC). Cairo, Egyptian Environmental Affairs Agency (EEAA)

EEAA (2017) Egypt state of the environment report 2017. Cairo, Egyptian Environmental Affairs Agency (EEAA)

Ellis F (2000) Rural livelihoods and diversity in developing countries. Oxford University Press, Oxford

Ellis F (2006) Livelihoods approach. In: Clarke D (ed) The Elgar companion to development studies. Edward Elgar, Cheltenham

Fafchamps M (2003) Rural poverty, risk and development. Edward Elgar, Cheltenham

Füssel H (2007) Vulnerability: a generally applicable conceptual framework for climate change research. Glob Environ Chang 17:155-167. https://doi.org/10.1016/j.gloenvcha.2006.05.002

Füssel H, Klein R (2006) Climate change vulnerability assessments: an evolution of conceptual thinking. Clim Chang 75:301-329. https:// doi.org/10.1007/s10584-006-0329-3

Gonzalez De La Rocha M (1994) The resources of poverty: women and survival in a Mexican City. Blackwell, Oxford

Hannigan J (1995) Environmental sociology: a social constructionist perspective. Routledge, London

Hareven T (1974) The family as process: the historical study of the family cycle. J Soc Hist 7:322-329. https://www.jstor.org/stable/3786310

Hemmati M, Röhr U (2007) A huge challenge and a narrow discourse: women and environments. University of Toronto, Toronto

Hoodfar H (1997) Between marriage and the market : intimate politics and survival in Cairo. University of California Press, Berkeley

Hopkins N, Mehanna S, El-Haggar S (2001) People and pollution: cultural constructions and social action in Egypt. American University in Cairo Press, Cairo

IPCC (2007) Climate change 2007: impacts, adaptation and vulnerability. In: Parry M, Canziani O, Palutikof J, Van der Linden P, Hanson C (eds) Contribution of Working Group II to the Fourth Assessment Report of the Intergovernmental Panel on Climate Change. Cambridge University Press, Cambridge

IPCC (2014) Climate change 2014: impacts, adaptation, and vulnerability. Part A: Global and sectoral aspects. Contribution of Working Group II to the Fifth Assessment Report of the Intergovernmental Panel on Climate Change. Cambridge, Cambridge University Press

Jackson C (2007) Resolving risk? Marriage and creative conjugality. Dev Chang 38:107-129. https://doi.org/10.1111/j.1467-7660.2007.00405.x

Jennings A (1995) The Nubians of West Aswan: village women in the midst of change. Lynne Rienner Publishers, London

Jennings A (2009) Nubian women of West Aswan: negotiating tradition and change. Lynne Rienner Publishers, London

Kabeer N (1994) Reversed realities: gender hierarchies in development thought. Verso Books, London

Kabeer N (1999) Resources, agency, achievements: reflections on the measurement of women's empowerment. Dev Chang 30:435-464. https://doi.org/10.1111/1467-7660.00125
Kabeer N, Assaad R, Darkwah A, Mahmud S, Sholkamy H et al (2013) Paid work, women's empowerment and inclusive growth: transforming the structures of constraint. New York, United Nations Entity for Gender Equality and the Empowerment of Women (UN Women)

Kandiyoti D (1998) Gender, power and contestation:"Bargaining with Patriarchy" Revisited. In: Pearson C (ed) Feminist visions of development: gender analysis and policy. Routledge, London

Kasperson R, Renn O, Slovic P, Brown H, Emel J et al (1988) The social amplification of risk: a conceptual framework. Risk Anal 8:177187. https://doi.org/10.1111/j.1539-6924.1988.tb01168.x

Macgregor S (2010) 'Gender and climate change': from impacts to discourses. J Indian Ocean Reg 6:223-238. https://doi.org/10.1080/ 19480881.2010.536669

O'Brien K, Eriksen S, Schjolden A, Nygaard I (2009) What's in a word? Conflicting interpretations of vulnerability in climate change research. Center for International Climate and Environmental Research (CICERO), Oslo

Pahl J (1989) Money and marriage. Macmillan Press, London

Rao N (2014) Caste, kinship, and life course: rethinking women's work and agency in rural South India. Fem Econ 20:78-102. https://doi. org/10.1080/13545701.2014.923578

Roncoli C (2006) Ethnographic and participatory approaches to research on farmers' responses to climate predictions. Clim Res 33:81-99. https://doi.org/10.3354/cr033081

Scoones I (1998) Sustainable rural livelihoods: a framework for analysis. University of Sussex, Brighton

Sen A (1982) Poverty and famines: an essay on entitlement and deprivation. Oxford University Press, Delhi

Sen A (1999) Development as freedom. Anchor Books, New York

Singerman D (1996) Engaging informality: women, work and politics in Cairo. In: Lobban R (ed) Middle Eastern women in the "Invisible" economy. University Press of Florida, Gainesville

Tadros M (2010) Egypt. In: Breslin S (ed) Women's rights in the Middle East and North Africa. Rowman \& Littlefield, New York

Terry G (2009) Climate change and gender justice. Practical Action Publishing \& Oxfam GB, Warwickshire

Terry G (2011) Climate, change and insecurity: views from a Gisu hillside. $\mathrm{PhD}$ thesis, University of East Anglia

Tschakert P, Machado M (2012) Gender justice and rights in climate change adaptation: opportunities and pitfalls. Ethics Soc Welfare 6:275-289. https://doi.org/10.1080/17496535.2012.704929

Tschakert P, Barnett J, Ellis N, Lawrence C, Tuana N et al (2017) Climate change and loss, as if people mattered: values, places, and experiences. Wiley Interdiscip Rev Clim Chang 8:5. https://doi.org/10. 1002/wcc. 476

Tschakert P, Ellis N, Anderson C, Kelly A, Obeng J (2019) One thousand ways to experience loss: a systematic analysis of climate-related intangible harm from around the world. Glob Environ Chang 55: 58-72. https://doi.org/10.1016/j.gloenvcha.2018.11.006

Tucker J, Daoud M, Oates N, Few R, Conway D et al (2015) Social vulnerability in three high-poverty climate change hot spots: what does the climate change literature tell us? Reg Environ Chang 15: 783-800. https://doi.org/10.1007/s10113-014-0741-6

White G (1988) Paths to risk analysis. Risk Anal 8:171-175. https://doi. org/10.1111/j.1539-6924.1988.tb01167.x

Whitehead A, Kabeer N (2001) Living with uncertainty: gender, livelihoods and pro-poor growth in rural sub-Saharan Africa. IDS Working Papers. Brighton, University of Sussex

Yin R (2004) The case study anthology. Sage, London

Publisher's note Springer Nature remains neutral with regard to jurisdictional claims in published maps and institutional affiliations. 